\title{
Lead biosorption onto waste beer yeast by-product, a means to decontaminate effluent generated from battery manufacturing industry
}

\author{
Krishnakumar Parvathi \\ Centre For Environmental Studies \\ Anna University \\ Chennai 600025 \\ Tamilnadu, India \\ Tel: 914422301283 \\ Fax: 914422354717 \\ E-mail: nag.np@hotmail.com \\ Ramachandramurthy Nagendran* \\ Centre For Environmental Studies \\ Anna University \\ Chennai 600025 \\ Tamilnadu, India \\ Tel: 914422301283 \\ Fax: 914422354717 \\ E-mail: nag.np@hotmail.com
Radhakrishnan Nareshkumar
Centre For Environmental Studies Anna University
Chennai 600025
Tamilnadu, India
Tel: 914422301283
Fax: 914422354717
E-mail: nag.np@hotmail.com

Financial support: Financial assistance to the first author in the form of a Research Fellowship from the University Grants Commission, New Delhi, India is acknowledged.

Keywords: biosorption, electrostatic attraction, Freundlich, Langmuir, functional group, lead, yeast.

This paper projects the potential of waste beer yeast Saccharomyces cerevisiae in biosorbing lead from battery manufacturing industrial effluent. Experiments were carried out as a function of $\mathrm{pH}$, biosorbent concentration, lead concentration and agitation speed. Specific lead uptake of $2.34 \mathrm{mg} / \mathrm{g}$ was recorded and the data gave good fits for Freundlich and Langmuir models with $\mathrm{K}_{\mathrm{f}}$ and $\mathrm{Q}$ max values of 0.5149 and 55.71 $\mathrm{mg} / \mathrm{g}$. The roles played by amines, carboxylic acids, phosphates, sulfhydryl group and lipids in lead biosorption were studied. Electrostatic attraction may be the mechanism of biosorption. The extent of contribution of the functional groups and lipids to lead biosorption was in the order: carboxylic acids $>$ lipids $>$ amines $>$ phosphates. Blocking of sulfhydryl group did not have any significant effect on lead uptake.

Heavy metals released by a number of industrial processes are major pollutants in marine, ground, industrial and even treated wastewaters (Martins et al. 2006). Lead is widely used in many industrial applications such as storage battery manufacturing, printing, pigments, fuels, photographic materials and explosive manufacturing (Jalali et al. 2002). Lead is highly toxic as its presence in drinking water above the permissible limit $(5 \mathrm{ng} / \mathrm{mL})$ causes adverse health effects such as anemia, encephalopathy, hepatitis and nephritic syndrome (Lo et al. 1999).

Conventionally, the following methods are employed for the removal of heavy metals from effluents: oxidation and reduction, precipitation, filtration, electrochemical treatment and evaporation (Baik et al. 2002). Physicochemical methods presently in use have several disadvantages such as unpredictable metal ion removal, high reagent requirements and formation of sludge and its disposal, in addition to high installation and operational costs (Deepa et al. 2006). Search for newer treatment technologies for removal of toxic metals from wastewaters has directed attention to biosorption (Veglio and Beolchini, 1997). It can be considered as an alternative technology for industrial wastewater treatment (Martins et al. 2006).

*Corresponding author 
The phenomenon of biosorption is defined as a metabolismindependent adsorption of pollutants based on the partition process on a microbial biomass (Ringot et al. 2006). It is a passive non-metabolically - mediated process of metal binding by biosorbent (Davis et al. 2003). Bacteria, yeasts, fungi and algae have been used as biosorbents of heavy metals. Among these, yeasts are known to be selective metal biosorbents as compared to fungi, actinomycetes and bacteria (Zouboulis et al. 1999).

Saccharomyces cerevisiae can remove toxic metals, recover precious metals and clean radio-nuclides from aqueous solutions to various extents. S. cerevisiae is not only a byproduct of established fermentation processes, but also can be easily obtained in considerably substantial quantities at low costs (Goksungur et al. 2005). Often, the economics of the process can be improved by using waste biosorbent instead of cultured biosorbent (Marques et al. 2000). The application of $S$. cerevisiae as a biosorbent not only removes metals from wastewaters but also eases the burden of disposal costs associated with the waste (Ting and Sun, 2000).

The yeast Saccharomyces cerevisiae has been used to remove $\mathrm{Cr}$ (VI), $\mathrm{Fe}(\mathrm{III})$ (Goyal et al. 2003), $\mathrm{Pb}$ (II) (Suh et al. 1998), $\mathrm{Cu}$ (II) (Jianlong, 2002), zinc and nickel (Zouboulis et al. 2001) from aqueous solutions. It can distinguish different metal species based on their toxicity, such as selenium, antimony and mercury. This kind of property makes $S$. cerevisiae useful not only for the bioremediation, removal or recovery of metal ions, but also for their analytical measurement (Wang and Chen, 2006).

Metal uptake by biosorption is reported to occur through interactions with functional groups native to the biomass cell wall (Goksungur et al. 2005). It is metabolismindependent and proceeds rapidly within several minutes by any one or a combination of the following metal binding mechanisms: coordination, complexation, ion exchange, physical adsorption (e.g. electrostatic) or inorganic microprecipitation. The mechanism of metal biosorption is complicated and not fully understood. The status of biomass (living or non-living), types of biomaterials, properties of metal-solution chemistry, ambient/environmental conditions such as $\mathrm{pH}$, will all influence the mechanism of metal biosorption (Wang and Chen, 2006). Identification of the functional groups would help to determine the mechanisms responsible for the binding of target metals (Ting and Teo, 1994). Pre-treating the biomass can help shed light on the role played by functional groups in biosorption of lead.

Biosorbents have been used to remove metals and other pollutants from laboratory prepared aqueous solutions thus far. Literature on the application of biosorption to 'real' industrial effluents is scarce, lead-bearing effluents in particular. The present study investigates the potential of waste beer yeast $S$. cerevisiae in biosorbing lead from battery manufacturing industrial effluent. The roles played by amines, carboxylic acids, phosphates, sulfhydryl group and lipids of $S$. cerevisiae in lead biosorption were also studied

\section{METHODS}

\section{Biosorbent}

Spent waste yeast biomass $S$. cerevisiae was collected from the fermentor at a brewery located near Chennai, India and transported to the laboratory in plastic containers. The yeast cells were washed thrice with double distilled water. After each wash, the biosorbent was separated by filtration using Whatmann No. 42 filter paper. The biosorbent was dried in a hot air oven at $80^{\circ} \mathrm{C}$ for $8 \mathrm{hrs}$ and stored for further use.

\section{Surface chemistry characterization of biosorbent}

Surface chemistry of the biosorbent was characterized by potentiometric titration and chemical treatment. The mechanism of biosorption was inferred from this.

Potentiometric titration of biosorbent. Ion exchange properties of (untreated) S. cerevisiae (also called as control in our study) with regard to $\mathrm{H}^{+}$and $\mathrm{OH}^{-}$ions were studied by potentiometric titration. The titration was performed in Erlenmeyer flasks using a magnetic stirrer (Heidolph MR $3001 \mathrm{~K}$, Germany) and pH meter (Elico, India). Protonation was carried out by soaking $1 \mathrm{~g}$ of dried biosorbent in $50 \mathrm{~mL}$ of $0.1 \mathrm{~mol} / \mathrm{L} \mathrm{HCl}$ and agitating for $2 \mathrm{hrs}$ on a rotary shaker (IKA-KS 501, Germany). The titration procedure was executed slowly, by stepwise addition of titrant $(0.1 \mathrm{~mol} / \mathrm{L}$ $\mathrm{NaOH})$ to the biosorbent slurry. After each addition of titrant of $0.25 \mathrm{~mL}$, the system was allowed to equilibrate until a stable reading was obtained. The potentiometric titration curve was obtained by plotting the volume of titrant against the recorded $\mathrm{pH}$.

Chemical treatment of biosorbent. Methylation of amines (Kapoor and Viraraghavan, 1997) was carried out by treating $1 \mathrm{~g}$ of raw biosorbent with $20 \mathrm{~mL}$ of formaldehyde and $40 \mathrm{~mL}$ of formic acid. The mixture was agitated on a rotary shaker (IKA- KS 501, Germany) for $5 \mathrm{hrs}$ at 150 rpm. The solution was filtered using Whatmann No. 42 filter paper and the biosorbent dried at $80^{\circ} \mathrm{C}$ for $8 \mathrm{hrs}$.

Esterification of carboxylic acids (Drake et al. 1996) was carried out by suspending $1 \mathrm{~g}$ of raw biosorbent in $65 \mathrm{~mL}$ of ethanol and $0.6 \mathrm{~mL}$ of concentrated hydrochloric acid. The mixture was shaken for $5 \mathrm{hrs}$ at $150 \mathrm{rpm}$. The solution was filtered and the biosorbent dried at $80^{\circ} \mathrm{C}$ for $8 \mathrm{hrs}$.

Esterification of phosphates (Fu and Viraraghavan, 2002) was carried out by heating $1 \mathrm{~g}$ of raw biosorbent in a mixture of $40 \mathrm{ml}$ triethyl phosphite and $30 \mathrm{~mL}$ nitromethane under reflux conditions for $6 \mathrm{hrs}$. The solution was filtered and the biosorbent dried at $80^{\circ} \mathrm{C}$ for $8 \mathrm{hrs}$.

Modification of sulfhydryl group (Gardea-Torresday et al. 1998) was carried out by dithiopyridine treatment. $1 \mathrm{~g}$ of raw biosorbent was washed in $0.1 \mathrm{~mol} / \mathrm{L} \mathrm{HCl}$ followed by $0.01 \mathrm{~mol} / \mathrm{L}$ sodium acetate at $\mathrm{pH} 5$. The biosorbent was then suspended in $0.001 \mathrm{~mol} / \mathrm{L}$ dithiopyridine (prepared by 
dissolving $0.22 \mathrm{~g}$ of 2,2, dithiopyridine in $2 \mathrm{~mL}$ of concentrated $\mathrm{HCl}$ and diluting to $1 \mathrm{~L}$ with $0.1 \mathrm{~mol} / \mathrm{L}$ sodium acetate at $\mathrm{pH} 5$ ). The mixture was then shaken for 5 hrs at $150 \mathrm{rpm}$. The solution was filtered and the biosorbent dried at $80^{\circ} \mathrm{C}$ for $8 \mathrm{hrs}$.

Extraction of lipids (Kapoor and Viraraghavan, 1997) was carried out by heating $1 \mathrm{~g}$ of raw biosorbent in $75 \mathrm{~mL}$ of benzene under reflux conditions for $6 \mathrm{hrs}$. The solution was filtered and the biosorbent dried at $80^{\circ} \mathrm{C}$ for $8 \mathrm{hrs}$.

\section{Collection and characterization of effluent}

Raw effluent was collected from a battery manufacturing unit and transported to the laboratory in plastic cans. The effluent was characterized for its physicochemical parameters following Standard Methods (APHA, 1998). Heavy metal analysis was carried out using Atomic Absorption Spectrophotometer (AAS 6VARIO, Analytik Jena, Germany). The $\mathrm{pH}$ of the effluent was not adjusted, unless otherwise stated. The characteristics of the effluent are listed in Table 1.

\section{Biosorption experiments}

A known weight of biosorbent was suspended in $100 \mathrm{~mL}$ of effluent taken in $250 \mathrm{~mL}$ Erlenmeyer flasks and agitated at $150 \mathrm{rpm}$ at $30^{\circ} \mathrm{C}$ on a rotary shaker. Samples were withdrawn periodically at fifteen-minute intervals during the 2 biosorption experiment and filtered using Whatmann No. 42 filter paper. The concentration of lead remaining in the filtrate was determined using AAS.

To study the effect of biosorbent concentration, dry biosorbent was added to the effluent to yield concentrations (w/v) of $0.5,1,1.5,2,2.5,3,3.5$ and $4 \%$ and biosorption experiments were carried out. Effect of $\mathrm{pH}$ on biosorption was investigated by adjusting and maintaining $\mathrm{pH}$ of the effluent at $\mathrm{pH}$ values of $1,2,3,4,5$ and 6 using $0.05 \mathrm{~mol} / \mathrm{L}$ $\mathrm{H}_{2} \mathrm{SO}_{4}$ and $1 \mathrm{~mol} / \mathrm{L} \mathrm{NaOH}$ with a biosorbent concentration of $2 \%$. Experiments were not conducted beyond $\mathrm{pH} 6$ to avoid lead precipitation. The effluent was diluted with double distilled water to yield solutions containing 25,50 , 75 and $100 \mathrm{mg} / \mathrm{L}$ of lead. These were subjected to biosorption, maintaining the biosorbent concentration constant at $2 \%$. Experiments were carried out by varying the agitation speed of the biosorption mixtures from 0 (no agitation - control), 50, 100, 150 to $200 \mathrm{rpm}$, with $2 \%$ biosorbent concentration.

\section{Calculation of lead uptake}

Lead uptake by biosorbent was calculated using the following mass balance equation for the biosorbent (Vieira and Volesky, 2003):

$$
q=\left[V\left(C_{i}-C_{f}\right)\right] / S
$$

where,

$q=$ lead uptake (mg metal/g cell dry weight);

$V=$ volume of metal-bearing solution contacted (batch) with the biosorbent (L);

$C_{i}=$ initial concentration of metal in solution $(\mathrm{mg} / \mathrm{L})$;

$C_{f}=$ final concentration of metal in solution $(\mathrm{mg} / \mathrm{L})$;

$S=$ dry weight of biosorbent added $(\mathrm{g})$.

\section{Biosorption models}

Freundlich (1906) and Langmuir (1916) isotherm models were used for interpreting the lead biosorption equilibrium. They are the earliest, most common and simplest known relationships describing the ad/bio-sorption phenomenon (Jalali et al. 2002).

The classical Freundlich equation is given below:

$$
q=K_{f} C_{e}^{1 / n}
$$

where,

$q=$ heavy metal adsorbed on the biosorbent (mg/g dry weight);

$C_{e}=$ final concentration of metal $(\mathrm{mg} / \mathrm{L})$ in the solution;

$K_{f}=$ an empirical constant that provides an indication of the adsorption capacity of biosorbent;

$n=$ an empirical constant that provides an indication of the intensity of adsorption.

Equation [2] can be linearized as follows:

$$
\log q=\log K_{f}+(1 / n) \log C_{e}
$$

The adsorption constants $\left(\mathrm{K}_{\mathrm{f}}\right.$ and $\left.1 / \mathrm{n}\right)$ were obtained by plotting $\log \mathrm{q}$ as a function of $\log \mathrm{C}_{\mathrm{e}}$.

The classical Langmuir equation is given below:

$$
q=\left(Q_{\max } b C_{e}\right) /\left(1+b C_{e}\right)
$$

where,

$q=$ heavy metal adsorbed on the biosorbent (mg/g dry weight);

$C_{e}=$ final concentration of metal $(\mathrm{mg} / \mathrm{L})$ in the solution;

$Q_{\max }=$ maximum possible amount of metallic ion adsorbed per unit weight of adsorbent;

$b=$ equilibrium constant related to the affinity of the binding sites for the metals.

Equation [4] can be linearized as follows:

$$
1 / q=\left(1 / q_{\max }\right)+\left(1 / q_{\max } b\right)\left(1 / C_{e}\right)
$$

The adsorption constants $\left(\mathrm{Q}_{\max }\right.$ and $\left.\mathrm{b}\right)$ were obtained by plotting $1 / \mathrm{q}$ as a function of $1 / \mathrm{C}_{\mathrm{e}}$.

\section{RESULTS AND DISCUSSION}

\section{Biosorbent surface characterization / Biosorption mechanism}

The potentiometric titration curve of untreated S. cerevisiae is shown in Figure 1. The results of titration experiments permit the qualitative and semi-quantitative determination 
of the nature of acidic sites present on the yeast cell wall. The curve shows three inflexion points: two at approximately $\mathrm{pH} 5$ and 6 corresponding to the pKa values of acidic groups and one at approximately $\mathrm{pH} 9$ corresponding to alkaline groups. It may be inferred that the two acidic groups are carboxylic and phosphate (Loukidou et al. 2004). The inflexion point around $\mathrm{pH} 9$ is comparable to the values reported for saturated amines (8.5-12.5) (Romero-González et al. 2001). These results are summarized and presented in Table 2.

Figure 2 and Table 3 present the effect of chemical modification of functional groups of S. cerevisiae. Control biosorbent (untreated) exhibited lead uptake of $2.34 \mathrm{mg} / \mathrm{g}$. The effects of chemically modifying the biosorbent are discussed in a step-wise manner in the following paragraphs.

The treatment of biosorbent with $\mathrm{HCHO}-\mathrm{HCOOH}$ causes methylation of amines present on the cell wall of biosorbent (Loudon, 1984). The reaction occurs as follows:

$$
\mathrm{RCH}_{2} \mathrm{NH}_{2} \stackrel{\mathrm{HCHO}, \mathrm{HCOOH}}{\rightarrow} \mathrm{RCH}_{2} \mathrm{~N}\left(\mathrm{CH}_{3}\right)_{2}+\mathrm{CO}_{2}+\mathrm{H}_{2} \mathrm{O}
$$

The methylation of amine groups prevents their participation in metal biosorption and hence reduces the biosorption efficiency. Therefore, the reduction in lead biosorption efficiency observed when amine-methylated biosorbent was used reveals that the amino group present in the cell wall of S. cerevisiae contributes towards biosorption of lead. A reduction of $53.38 \%$ in lead biosorption was recorded due to this modification (Table 3). Jianlong (2002) has reported similar reduction in biosorption of copper by HCHO-modified S. cerevisiae. Copper biosorption has been reported to be affected due to modification of carboxyl group present in the cell wall of Aspergillus niger (Akthar et al. 1996).

Ethanol treatment of biosorbent drastically reduced lead biosorption capacity of the biomass (Figure 2). According to Drake et al. (1996), treatment of biosorbent with methanol results in esterification of carboxylic acids present on the cell wall of biosorbent and the reaction occurs as follows:

$$
\mathrm{RCOOH}+\mathrm{CH}_{3} \mathrm{OH} \stackrel{\mathrm{H}^{+}}{\rightarrow} \mathrm{RCOOCH}_{3}+\mathrm{H}_{2} \mathrm{O}
$$

In this study, ethanol was used instead of methanol. Hence, on a similar chemistry, when S. cerevisiae is treated with ethanol in the presence of concentrated $\mathrm{HCl}$, the carboxylic acids present on the cell wall may be esterified as follows:

$$
\mathrm{RCOOH}+\mathrm{CH}_{3} \mathrm{CH}_{2} \mathrm{OH} \stackrel{\mathrm{H}^{+}}{\rightarrow} \mathrm{RCOOCH}_{2} \mathrm{CH}_{3}+\mathrm{H}_{2} \mathrm{O} \text { [6] }
$$

The drastic reduction in lead biosorption by $96.34 \%$ (from Table 3) when ethanol treated biosorbent was used, reveals that the carboxylic group on the cell wall of S. cerevisiae contributes most significantly to lead biosorption. Beveridge and Murray (1980) observed that modification of carboxyl groups on Bacillus subtilis decreased copper biosorption. A similar observation of reduced binding of copper to methanol-modified S. cerevisiae has been reported by Jianlong (2002). Cohen-Shoel et al. (2002) observed decreased biosorption of strontium (II) by carboxyl-methylated Azolla sp. Gardea-Torresday et al. (1995) have reported that $\mathrm{Cu}$ (II) binding decreased approximately by $25 \%$ after the carboxyl groups on the cell wall of Mucor rouxii were esterified with methanol. They concluded that covalent blocking of carboxyl groups in $\mathrm{M}$. rouxii reduced the number of metal binding sites.

Treating the biosorbent with a mixture of triethyl phosphate and nitromethane reduced lead uptake by $0.42 \mathrm{mg} / \mathrm{g}$, thus resulting in a percentage negative effect of $17.61 \%$. This treatment is reported to result in esterification of phosphate group (Markowska et al. 1975). Hence the reduction of lead uptake indicates that phosphates in the yeast were also binding sites for $\mathrm{Pb} 2+$. But this reduction of biosorption capacity was not very significant, which indicated that they were not the major binding sites.

Dithiopyridine-treated biosorbent almost retained the lead biosorption capacity of the original (untreated) biosorbent. By the treatment of 2,2-dithiopyridine to the biosorbent, the available sulfhydryl groups should be chemically blocked and converted to thiol groups as shown in Figure 3 (Gardea-Torresday et al. 1995). But, lead uptake of 2.285 $\mathrm{mg} / \mathrm{g}$ by treated biosorbent was recorded as against 2.34 $\mathrm{mg} / \mathrm{g}$ by untreated biosorbent. Only a marginal decrease of $2.35 \%$ was observed after treatment. This suggests that sulfhydryl groups do not play any significant role in the binding of lead. Gardea-Torresday et al. (1995) have also reported almost insignificant difference in uptake of copper(II), lead(II) and nickel(II) between dithiopyridinetreated and untreated alfalfa biosorbent.

Biosorbent treated with benzene exhibited a negative effect of $35.68 \%$ reduction in lead biosorption. The treatment of biosorbent with benzene extracts the lipid fraction of biosorbent (Tobin et al. 1990). Therefore, the reduction in biosorption efficiency when benzene treated biosorbent was used, reveals that the lipids in the cell wall of S. cerevisiae contribute to lead biosorption. Kapoor and Viraraghavan (1997) observed slight decreases in biosorption of lead, cadmium and copper when lipids were extracted from Aspergillus niger. They attributed the decrease to either lipid extraction or the probable structural changes that may have resulted due to the harsh conditions of the extraction process.

The carboxyl, phosphate and amino groups and lipids which contribute most to lead biosorption are negatively charged. However, the interaction between amino group and lead ion is complexation. This research showed that the electrostatic attraction and complexation seem to be the most important mechanism of biosorption of metal cation $(\mathrm{Pb}(\mathrm{II})$ in this case $)$. 


\section{Biosorption experiments}

Biosorption of lead with varying biosorbent concentration is shown in Figure 4. Lead uptake rose from $0.38 \mathrm{mg} / \mathrm{g}$ to $2.34 \mathrm{mg} / \mathrm{g}$ with increase in biosorbent concentration from $0.5 \%$ to $2 \%$. Lead uptake decreased slightly when the biosorbent concentration reached $4 \%(2 \mathrm{mg} / \mathrm{g})$. A similar trend in metal uptake with variations in biosorbent concentration has been reported for lead biosorption from its synthetic aqueous solutions by Spirulina maxima by Gong et al. (2005). High biosorbent concentrations are known to cause cell agglomeration and consequent reduction in inter-cellular distance. This is reported to produce a 'screen effect' among the dense layer of cells, leading to 'protection' of the binding sites from metal ions (Pons and Fuste, 1993). In other words, metal uptake is higher when the inter-cellular distance is more (at low biosorbent concentration), as this condition ensures optimal electrostatic interaction between cells, a significant factor for biosorption (Itoh et al. 1975).

Lead uptake increased gradually with rise in initial $\mathrm{pH}$ from 1 to 5 , with a highest value of $2.109 \mathrm{mg} / \mathrm{g}$ at $\mathrm{pH} 5$ (Figure $5)$. It is well known that both the cell surface metal binding sites and the availability of metal in solution are affected by $\mathrm{pH}$ (Ahuja et al. 1999). At low $\mathrm{pH}$, the cell surface sites are closely linked to the $\mathrm{H}+$ ions, thereby making these unavailable for other cations. However, with an increase in $\mathrm{pH}$, there is an increase in ligands with negative charges which results in increased binding of cations. However, at $\mathrm{pH} 6$, the lead uptake decreased to $1.78 \mathrm{mg} / \mathrm{g}$ due to its partial precipitation.

Biosorption increased with rise in lead concentration in the effluent (Figure 6). A rise in lead concentration from 25 to $100 \mathrm{mg} / \mathrm{L}$ resulted in an increase in its uptake by $\mathrm{S}$. cerevisiae from 0.75 to $2.34 \mathrm{mg} / \mathrm{g}$ (more than 3-fold), respectively. Similar performance by Neurospora crassa during studies on lead biosorption from its synthetic aqueous solutions has been reported by Kiran et al. (2005).

Figure 7 presents the effect of agitation speed on lead biosorption by $\mathrm{S}$. cerevisiae. Control units at $0 \mathrm{rpm}$ (no agitation) exhibited very low lead uptake $(0.14 \mathrm{mg} / \mathrm{g})$. Lead uptake increased more than 3 -fold from $0.72 \mathrm{mg} / \mathrm{g}$ to 2.34 $\mathrm{mg} / \mathrm{g}$ with rise in agitation speed from 50 to $150 \mathrm{rpm}$, beyond which there was no further increase. Similar trends in biosorption of cadmium and lead by Sargassum sp. have been reported by Cruz et al. (2004) and Martins et al. (2006), respectively. Lower metal uptake at higher agitation speeds beyond a point is attributed to non-homogeneity of the biosorption mixtures (Selatnia et al. 2004) as a result of vortex phenomenon. Highest uptake of lead at an agitation speed of $150 \mathrm{rpm}$ observed during the study indicates that the system experienced least mass transfer resistance. Thus, biosorption can be conducted at this speed and no further enhancement is needed to make the binding sites readily available for lead uptake. It is known that external mass transfer resistance is directly proportional to the thickness of the stationary fluid layer surrounding the biosorbent particles. The film thickness in turn is controlled by the agitation speed of the bulk solution. A higher agitation speed decreases the film thickness and eventually eliminates film resistance (Vilar et al 2005).

\section{Biosorption models}

The uptake of metal ions by microorganisms in batch systems occurs in two stages: an initial rapid stage marked by passive uptake, followed by a much slower process with active uptake. The first stage is physical adsorption or ion exchange at the surface of the biosorbent. The adsorption equilibrium occurs at the end of rapid physical adsorption. The Freundlich and Langmuir adsorption isotherm equations are frequently used to represent this equilibrium.

The Freundlich adsorption isotherm for lead biosorption by S. cerevisiae is given in Figure 8. Values of $\mathrm{Kf}$ and $1 / \mathrm{n}$ obtained from the isotherm are compared in Table 4. The magnitude of $\mathrm{Kf}$ and $1 / \mathrm{n}$ illustrate the separation of metal ions from wastewater and the adsorption capacity of the yeast $(\mathrm{Kf}=0.5149)$. The Freundlich adsorption equation thus arrived at is: $\mathrm{q}=0.5194 \mathrm{C}_{\mathrm{e}}^{1.1871}$. The Langmuir adsorption isotherm for lead biosorption by $\mathrm{S}$. cerevisiae is plotted in Figure 9. Values of Qmax and b obtained from the isotherm are compared in Table 4. Qmax value of 55.71 $\mathrm{mg} / \mathrm{g}$ for S. cerevisiae indicates high metal uptake by the biosorbent. The Langmuir adsorption equation thus arrived at is: $\mathrm{q}=[55.71 \times 0.0883 \times \mathrm{Ce}] /[1+(0.0883 \times \mathrm{Ce})]$.

Table 5 gives a comparison of the Freundlich and Langmuir isotherm constants available in literature for lead biosorption by various biosorbents. Comparatively lower Kf value (0.5149) was observed in the present study. This may be due to the presence of ions other than lead in the effluent which decrease the specificity of Saccharomyces cerevisiae for lead. However, the Qmax value of 55.71 $\mathrm{mg} / \mathrm{g}$ is indicative of high biosorption potential of the biomass.

Biosorption is basically at lab scale in spite of its development for tens of years (Wang and Chen, 2006). The mechanisms involved in biosorption or metal-microbe interactions should be further studied with great efforts by utilizing various techniques and the combination of them (Kratochvil and Volesky, 1998). They can be further elucidated using mathematical and dynamic models, in combination with molecular biotechnology tools. Various aspects which shed light on the application of biosorption on an industrial scale include:

- Physicochemical characteristics of 'real' wastewater on the basis of thermodynamics and reaction kinetics. 
- Screening of biosorbents for high metal-binding capacity and selectivity.

- Optimization of parameters.

- Combination of biosorption with physicochemical treatment technologies for 'complete' wastewater treatment and recovery/reuse of metals.

The present study is a small step towards such an approach in characterizing the biosorption process on the basis of thermodynamics and reaction kinetics and optimizing the process-affecting parameters. Studies in the direction of reuse/regeneration of lead-loaded yeast are in progress in our laboratory.

\section{CONCLUDING REMARKS}

This study showed that waste beer yeast can efficiently remove lead from battery manufacturing industrial effluents. This study also emphasizes the importance and need for carrying out extended testing for the compatibility of biosorption to a specific industrial effluent. As regards the cost of waste beer yeast, it can be obtained free of charge or at low cost from the respective industries, since it already presents disposal problems/cost to them. The findings of the study indicate that biosorption is a promising technology for removal of lead from battery manufacturing effluent. However, further studies with respect to metal-biosorbent specificity, applicability to various other types of metal-laden effluents and large scale studies will help fine-tune the biosorption technology for large-scale application.

\section{REFERENCES}

AHUJA, P.; GUPTA, R. and SAXENA, R.K. Sorption and desorption of cobalt by Oscillatoria anguistissima. Current Microbiology, July 1999, vol. 39, no. 1, p. 49-52.

AKTHAR, Md. Naseem; SASTRY, K. Sivarama and MOHAN, P. Maruthi. Mechanism of metal ion biosorption by fungal biomass. BioMetals, January 1996, vol. 9, no. 1, p. 21-28.

AMERICAN PUBLIC HEALTH ASSOCIATION (APHA). Standard Methods for the Examination of Water and Wastewater. $20^{\text {th }}$ ed. Washington DC, APHA Publications, 1998. ISBN 0-87-553060-5.

BAIK, W.Y.; BAE, J.H.; CHO, K.M. and HARTMEIER, $\mathrm{W}$. Biosorption of heavy metals using whole mold mycelia and parts thereof. Bioresource Technology, February 2002, vol. 81, no. 3, p. 167-170.

BEVERIDGE, T.J. and MURRAY, R.G.E. Sites of metal deposition in the cell wall of Bacillus subtilis. Journal of Bacteriology, February 1980, vol. 141, no. 2, p. 876-887.

COHEN-SHOEL, N.; ILZYCER, D.; GILATH, I. and
TEL-OR, E. The involvement of pectin in $\mathrm{Sr}^{2+}$ biosorption by Azolla. Water, Air and Soil Pollution, March 2002, vol. 135, no. 1-4, p. 195-205.

CRUZ, Claudio C.V.; DA COSTA, Antonio Carlos A.; HENRIQUES, Cristiane Assumpcao and LUNA, Aderval S. Kinetic modeling and equilibrium studies during cadmium biosorption by dead Sargassum $s p$. biomass. Bioresource Technology, February 2004, vol. 91, no. 3, p. 249-257.

DAVIS, Thomas A.; VOLESKY, Bohumil and MUCCI, Alfonso. A review of the biochemistry of heavy metal biosorption by brown algae. Water Research, November 2003, vol. 37 , no. 18 , p. 4311-4330.

DEEPA，K.K.; SATHISHKUMAR， M.; BINUPRIYA, A.R.; MURUGESAN, G.S.; SWAMINATHAN, K. and YUN, S.E. Sorption of $\mathrm{Cr}(\mathrm{VI})$ from dilute solutions and wastewater by live and pretreated biomass of Aspergillus flavus. Chemosphere, February 2006, vol. 62, no. 5, p. 833840.

DRAKE, Lawrence R.; LIN, Shan; RAYSON, Gary D. and JACKSON, Paul J. Chemical modification and metal binding studies of Datura innoxia. Environmental Science and Technology, January 1996, vol. 30, no. 1, p. 110-114.

FREUNDLICH, H.M.F. Over the adsorption in solution. Journal of Physical Chemistry, 1906, vol. 57A, p. 385-470.

FU, Y. and VIRARAGHAVAN, T. Dye biosorption sites in Aspergillus niger. Bioresource Technology, April 2002, vol. 82, no. 2, p. 139-145.

GARDEA-TORRESDAY, J.L.; CANO-AGUILERA, I.; TIEMANN, K.J.; WEBB, R. and GUTIERREZ-CORONA, F. Copper binding by inactivated cells of Mucor rouxii. In: Proceeding of the $10^{\text {th }}$ Annual Conference on Hazardous Waste Research $\left(23^{\text {rd }}-24^{\text {th }}\right.$ May, 1995, Manhattan, Kansas, USA). 1995. p. 33-40. Available from Internet: http://www.engg.ksu.edu/HSRC/95Proceed/cano.pdf.

GARDEA-TORRESDEY， J.L.; TIEMANN， K.J.; DOKKEN, K. and GAMEZ, G. Investigation of metal binding in alfalfa biomass through chemical modification of amino and sulfhy-dryl ligands. In: Proceeding of the 1998 Conference on Hazardous Waste Research $\left(18^{\text {th }}-21^{\text {st }}\right.$ May, 1998, Snowbird, Utah, USA). 1998. p. 111-121. Available from Internet: http://www.engg.ksu.edu/hsrc/98Proceed/10Gardea1/10gar dea1.pdf.

GOKSUNGUR, Yekta; ÜREN, Sibel and GÜVENÇ, Ulgar. Biosorption of cadmium and lead ions by ethanol treated waste baker's yeast biomass. Bioresource Technology, January 2005, vol. 96, no. 1, p. 103-109.

GONG, Renmin; DING, Yi; LIU, Huijun; CHEN, Qiuyi and LIU, Zhili. Lead biosorption and desorption by intact 
and pretreated Spirulina maxima biomass. Chemosphere, January 2005, vol. 58, no. 1, p. 125-130.

GOYAL, N.; JAIN, S.C. and BANERJEE, U.C. Comparative studies on the microbial adsorption of heavy metals. Advances in Environmental Research, January 2003, vol. 7, no. 2, p. 311-319.

ITOH, Michio; YUASA, Mitsuyoshi and KOBAYASHI, Teruaki. Adsorption of metal ions on yeast cells at varied cell concentrations. Plant and Cell Physiology, December 1975 , vol. 16 , no. 6 , p. 1167-1169.

JALALI, R.; GHAFOURIAN, H.; ASEF, Y.; DAVARPANAH, S.J. and SEPEHR, S. Removal and recovery of lead using non living biomass of marine algae. Journal of Hazardous Materials, June 2002, vol. 92, no. 3, p. $253-262$.

JIANLONG, Wang. Biosorption of copper (II) by chemically modified biomass of Saccharomyces cerevisiae. Process Biochemistry, March 2002, vol. 37, no. 8, p. 847850.

KAPOOR, A. and VIRARAGHAVAN, T. Heavy metal biosorption sites in Aspergillus niger. Bioresource Technology, September 1997, vol. 61, no. 3, p. 221-227.

KIRAN, Ismail; AKAR, Tamer and TUNALI, Sibel. Biosorption of $\mathrm{Pb}$ (II) and $\mathrm{Cu}$ (II) from aqueous solutions by pretreated biomass of Neurospora crassa. Process Biochemistry, November 2005, vol. 40, no. 11, p. 35503558.

KOGEJ, Adela and PAVKO, Aleksander. Comparison of Rhizopus nigricans in a pelleted growth form with some other types of waste microbial biomass as biosorbents for metal ions. World Journal of Microbiology and Biotechnology, October 2001, vol. 17, no. 7, p. 677-685.

KRATOCHVIL, David and VOLESKY, Bohumil. Advances in the biosorption of heavy metals. Trends in Biotechnology, July 1998, vol. 16, no. 7, p. 291-300.

LANGMUIR, Irving. The constitution and fundamental properties of solids and liquids. Part. I: Solids. Journal of the American Chemical Society, November 1916, vol. 38, no. 11, p. 2221-2295.

LO, Waihung; CHUA, Hong; LAM, Kim-Hung and BI, Shu-Ping. A comparative investigation on the biosorption of lead by filamentous fungal biomass. Chemosphere, December 1999, vol. 39, no. 15, p. 2723-2736.

LOUDON, G. Marc. Organic Chemistry. Reading, Massachusetts, 1984, 1150 p. ISBN 0201144387.

LOUKIDOU, Maria X.; ZOUBOULIS, Anastasios I.; KARAPANTSIOS, Thodoris D. and MATIS, Kostas A. Equilibrium and kinetic modeling of chromium(VI) biosorption by Aeromonas caviae. Colloids and Surfaces A: Physicochemical and Engineering Aspects, August 2004, vol. 242, no. 1-3, p. 93-104.

LU, Wei-Bin; SHI, Jun-Ji; WANG, Ching-Hsiung and CHANG, Jo-Shu. Biosorption of lead, copper and cadmium by an indigenous isolate Enterobacter sp. J1 possessing high heavy-metal resistance. Journal of Hazardous Materials, June 2006, vol. 134, no. 1-3, p. 80-86.

MARKOWSKA, Anna; OLEJNIK, Jadwiga and MICHALSKI, Jan. Selektive alkylierung von mehrbasigen säuren des 4-bindigen phosphors mit trialkylphosphit. Chemische Berichte, August 1975, vol. 108, no. 8, p. 25892592.

MARQUES, P.A.S.S.; ROSA, M.F. and PINHEIRO, H.M. $\mathrm{pH}$ effects on the removal of $\mathrm{Cu}^{2+}, \mathrm{Cd}^{2+}$ and $\mathrm{Pb}^{2+}$ from aqueous solution by waste brewery biomass. Bioprocess and Biosystems Engineering, August 2000, vol. 23, no. 2, p. 135-141.

MARTINS, Bruno L.; CRUZ, Claudio C.V.; LUNA, Aderval S. and HENRIQUES, Cristiane A. Sorption and desorption of $\mathrm{Pb}^{2+}$ ions by dead Sargassum sp. biomass. Biochemical Engineering Journal, January 2006, vol. 27, no. 3, p. 310-314.

PONS, M. Pilar and FUSTE, M. Carmen. Uranium uptake by immobilized cells of Pseudomonas strain EPS 5028 . Applied Microbiology and Biotechnology, July 1993, vol. 39, no. 4-5, p. 661-665.

QUEK, S.Y.; WASE, D.A.J. and FORSTER, C.F. The use of sago waste for the sorption of lead and copper. Water SA, July 1998, vol. 24, no. 3, p. 251-256.

RINGOT, Diana; LERZY, Benoit; CHAPLAIN, Kathy; BONHOURE, Jean-Paul; AUCLAIR, Eric and LARONDELLE, Yvan. In vitro biosorption of ochratoxin A on the yeast industry by-products: Comparison of isotherm models. Bioresource Technology, August 2006.

ROMERO-GONZALEZ, Maria E.; WILLIAMS, Ceri J. and GARDINER, Philip E. Study of the mechanisms of cadmium biosorption by dealginated seaweed waste. Environmental Science and Technology, July 2001, vol. 35, no. 14 , p. 3025-3030.

SELATNIA, A.; BOUKAZOULA, A.; KECHID, B.N.; BAKHTI, M.Z; CHERGUI, A. and KERCHICH, Y. Biosorption of lead (II) from aqueous solution by a bacterial dead Streptomyces rimosus biomass. Biochemical Engineering Journal, July 2004, vol. 19, no. 2, p. 127-135.

SUH, Jung Ho; KIM, Dong Seog; YUN, Jong Won and 
SONG, Seung Koo. Process of $\mathrm{Pb}^{2+}$ accumulation in Saccharomyces cerevisiae. Biotechnology Letters, February 1998, vol. 20, no. 2, p. 153-156.

TING, Yen-Peng and SUN, Gang. Use of polyvinyl alcohol as a cell immobilization matrix for copper biosorption by yeast cells. Journal of Chemical Technology and Biotechnology, July 2000, vol. 75, no. 7, p. 541-546.

TING, Y-P. and TEO, W.K. Uptake of cadmium and zinc by yeast: effects of co-metal ion and physical/chemical treatments. Bioresource Technology, 1994, vol. 50, no. 2, p. 113-117.

TOBIN, J.M.; COOPER, D.G. and NEUFELD, R.J. Investigation of the mechanism of metal uptake by denatured Rhizopus arrhizus biomass. Enzyme and Microbial Technology, August 1990, vol. 12, no. 8, p. 591595.

VEGLIO, F. and BEOLCHINI, F. Removal of metals by biosorption: a review. Hydrometallurgy, March 1997, vol. 44, no. 3, p. 301-316.

VIEIRA, Regine H.S.F. and VOLESKY, Boya. Biosorption: a solution to pollution? International Microbiology, March 2003, vol. 3, no. 1, p. 17-24.

VILAR, Vitor J.P.; SEBESTA, Ferdinand; BOTELHO, Cidália M.S. and BOAVENTURA, Rui A.R. Equilibrium and kinetic modelling of $\mathrm{Pb}^{2+}$ biosorption by granulated agar extraction algal waste. Process Biochemistry, October 2005, vol. 40, no. 10, p. 3276-3284.

WANG, Jianlong and CHEN, Can. Biosorption of heavy metals by Saccharomyces cerevisiae: A review. Biotechnology Advances, September-October 2006, vol. 24, no. 5 , p. $427-451$.

YETIS, Ulku; DOLEK, Ayla; DILEK, Filiz B. and OZCENGIZ, Gulay. The removal of $\mathrm{Pb}$ (II) by Phanerochaete chrysosporium. Water Research, November 2000, vol. 34, no. 16, p. 4090-4100.

ZOUBOULIS, Anastasios I.; ROUSOU, Elen G.; MATIS, Kostas A. and HANCOCK, Ian C. Removal of toxic metals from aqueous mixtures. Part 1: Biosorption. Journal of Chemical Technology and Biotechnology, May 1999, vol. 74 , no. 5, p. 429-436.

ZOUBOULIS, Anastasios I.; MATIS, Kostas A. and LAZARIDIS, N.K. Removal of metal ions from simulated wastewater by Saccharomyces yeast biomass: combining biosorption and flotation processes. Separation Science and Technology, 2001, vol. 36, no. 3, p. 349-365. 


\section{APPENDIX}

\section{Figures}

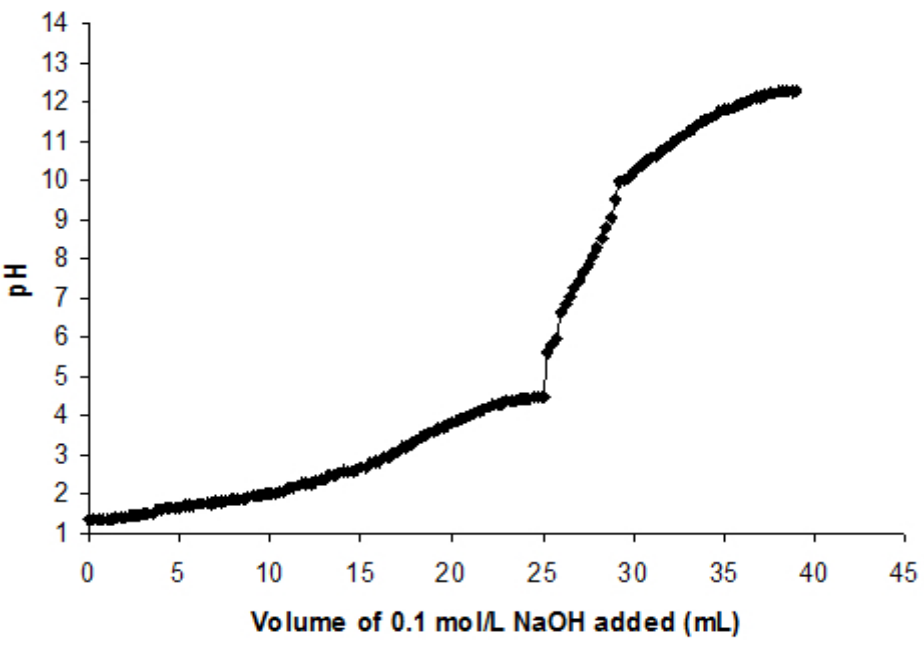

Figure 1. Potentiometric titration curve of Saccharomyces cerevisiae.

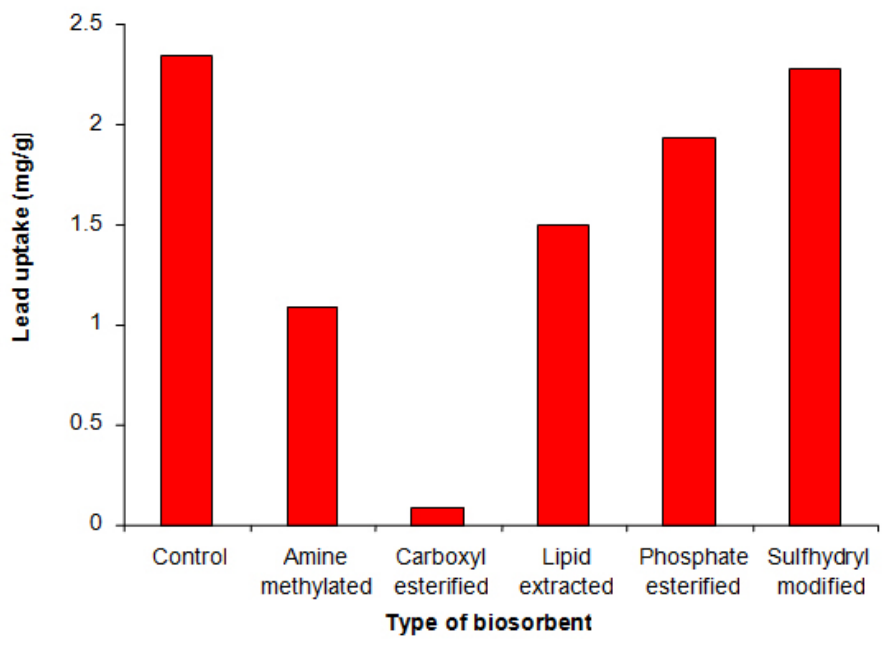

Figure 2. Effect of chemical treatment of Saccharomyces cerevisiae on lead biosorption from battery manufacturing industrial effluent. The deviations within duplicates are too small to be plotted as error bars $(<1 \%)$.

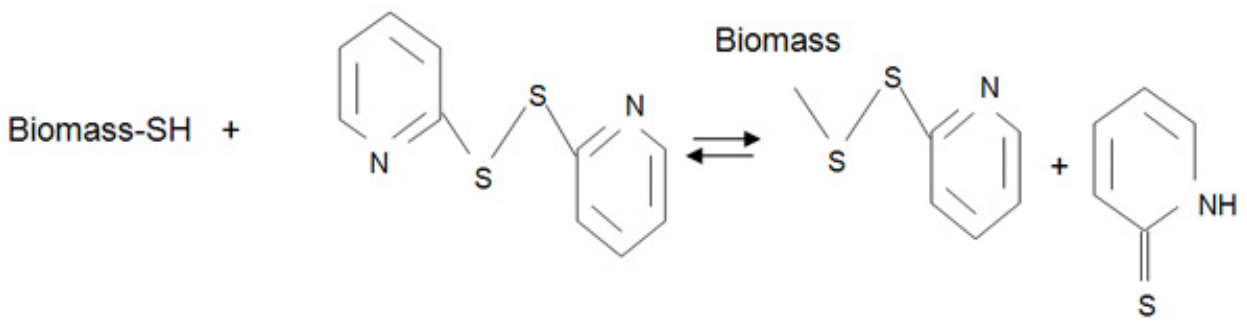

Figure 3. Chemical modification of sulfhydryl group. 


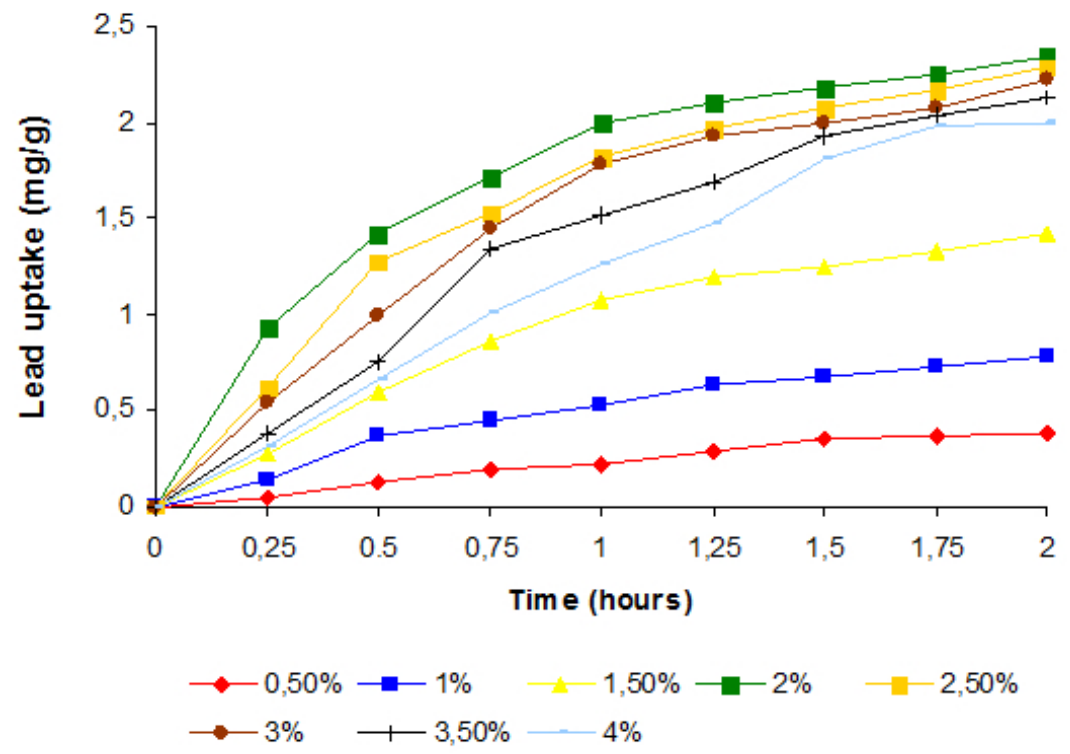

Figure 4. Effect of biomass concentration on lead biosorption by Saccharomyces cerevisiae from battery manufacturing industrial effluent. The deviations within duplicates are too small to be plotted as error bars $(<1 \%)$.

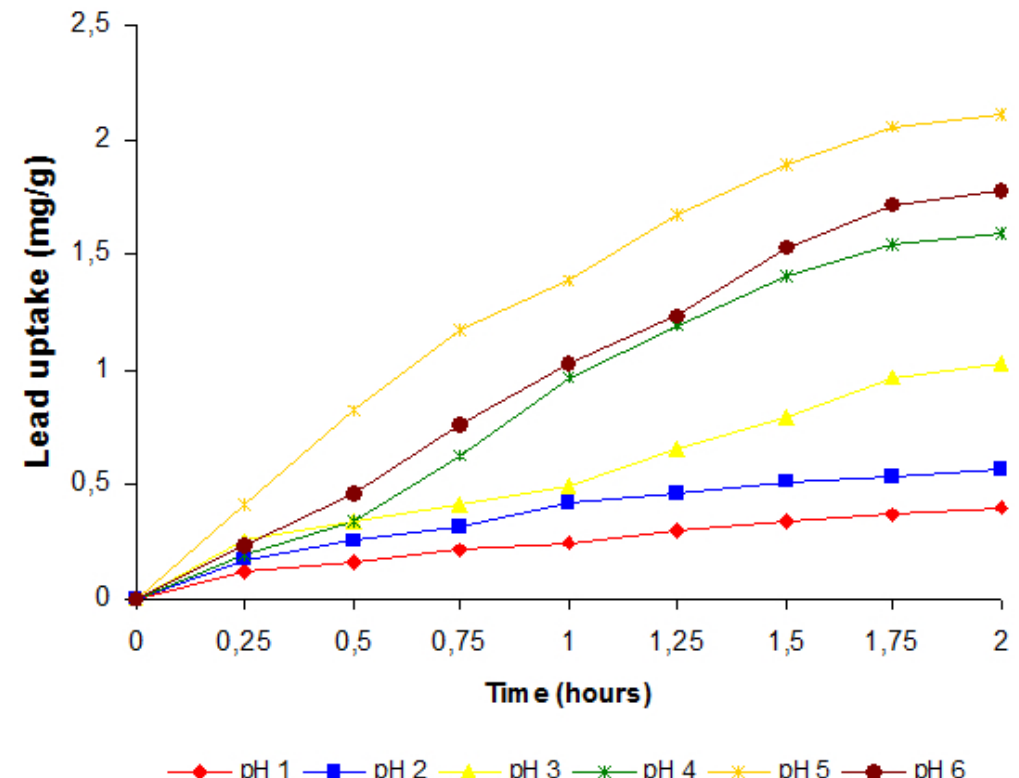

Figure 5. Effect of pH on lead biosorption by Saccharomyces cerevisiae from battery manufacturing industrial effluent. The deviations within duplicates are too small to be plotted as error bars (<1\%). 


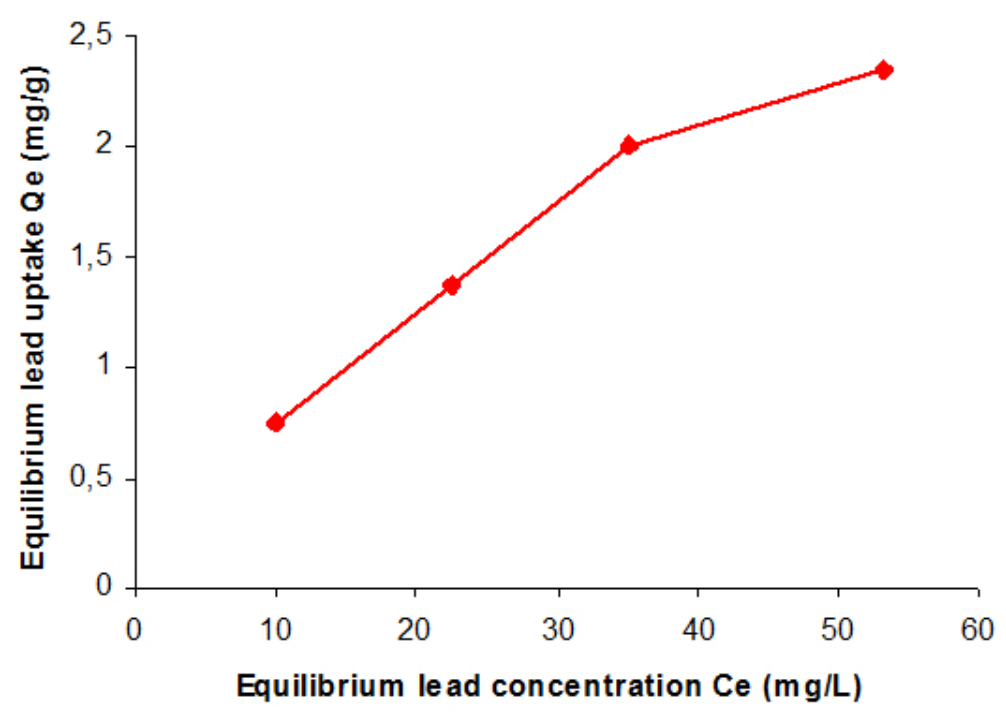

Figure 6. Effect of lead concentration on biosorption by Saccharomyces cerevisiae from battery manufacturing industrial effluent. The deviations within duplicates are too small to be plotted as error bars $(<1 \%)$.

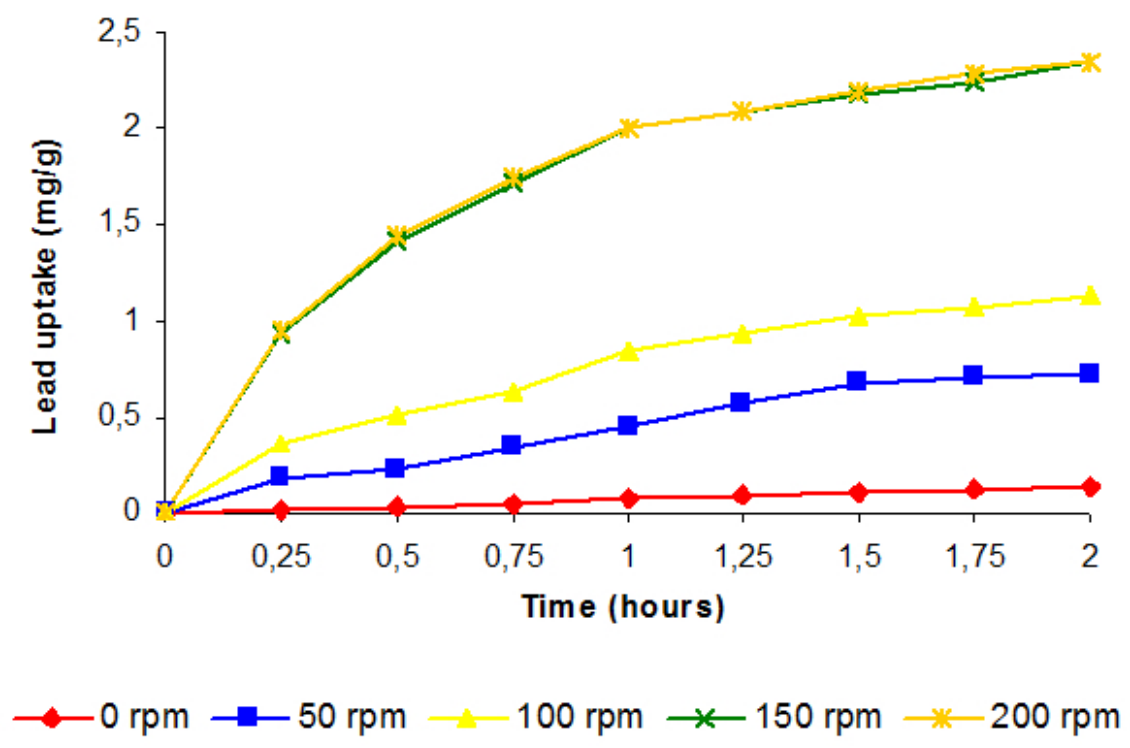

Figure 7. Effect of agitation speed on lead biosorption by Saccharomyces cerevisiae from battery manufacturing industrial effluent. The deviations within duplicates are too small to be plotted as error bars $(<1 \%)$. 
Parvathi, K. et al.

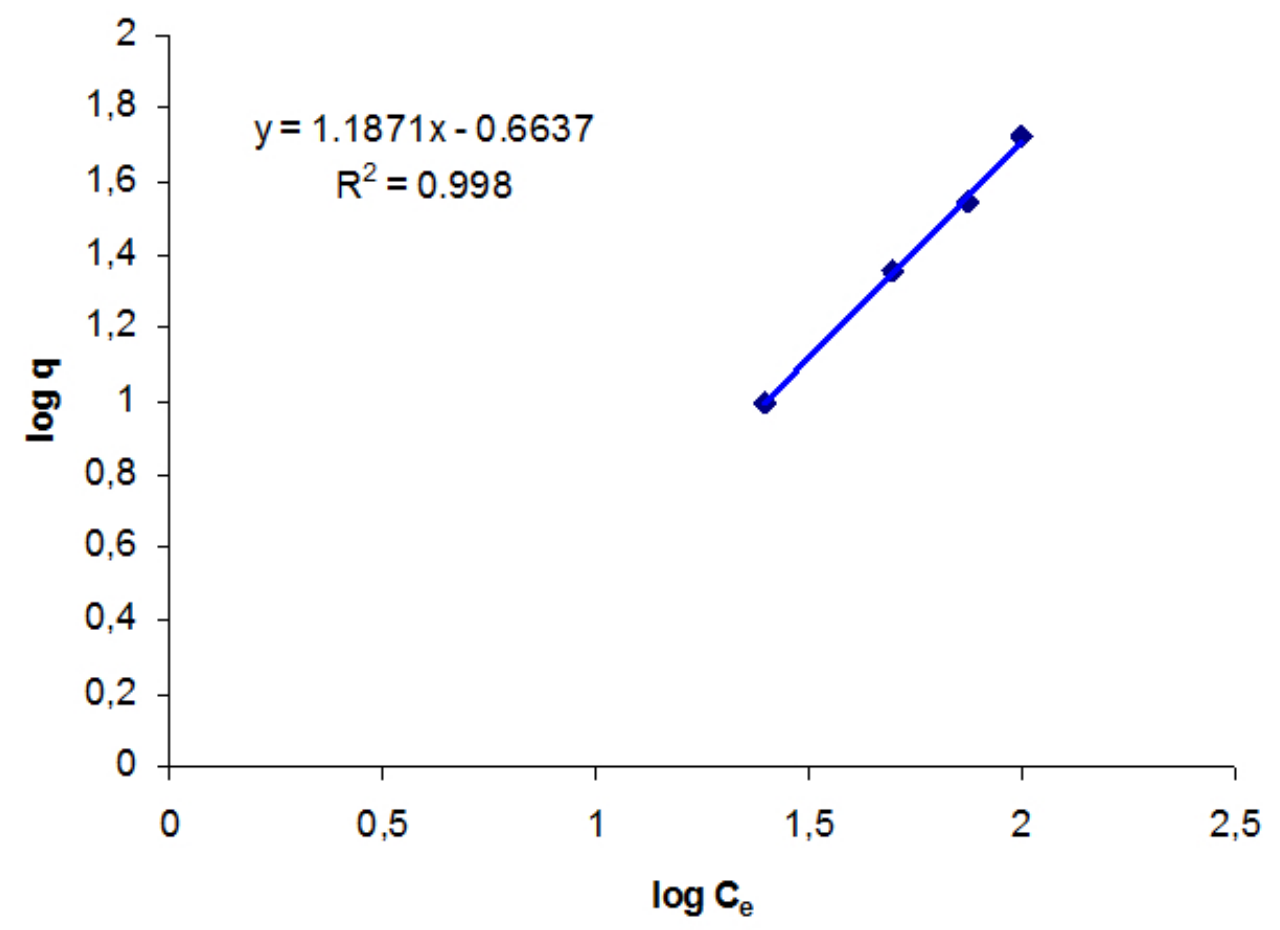

Figure 8. Freundlich isotherm for lead biosorption by Saccharomyces cerevisiae from battery manufacturing industrial effluent.

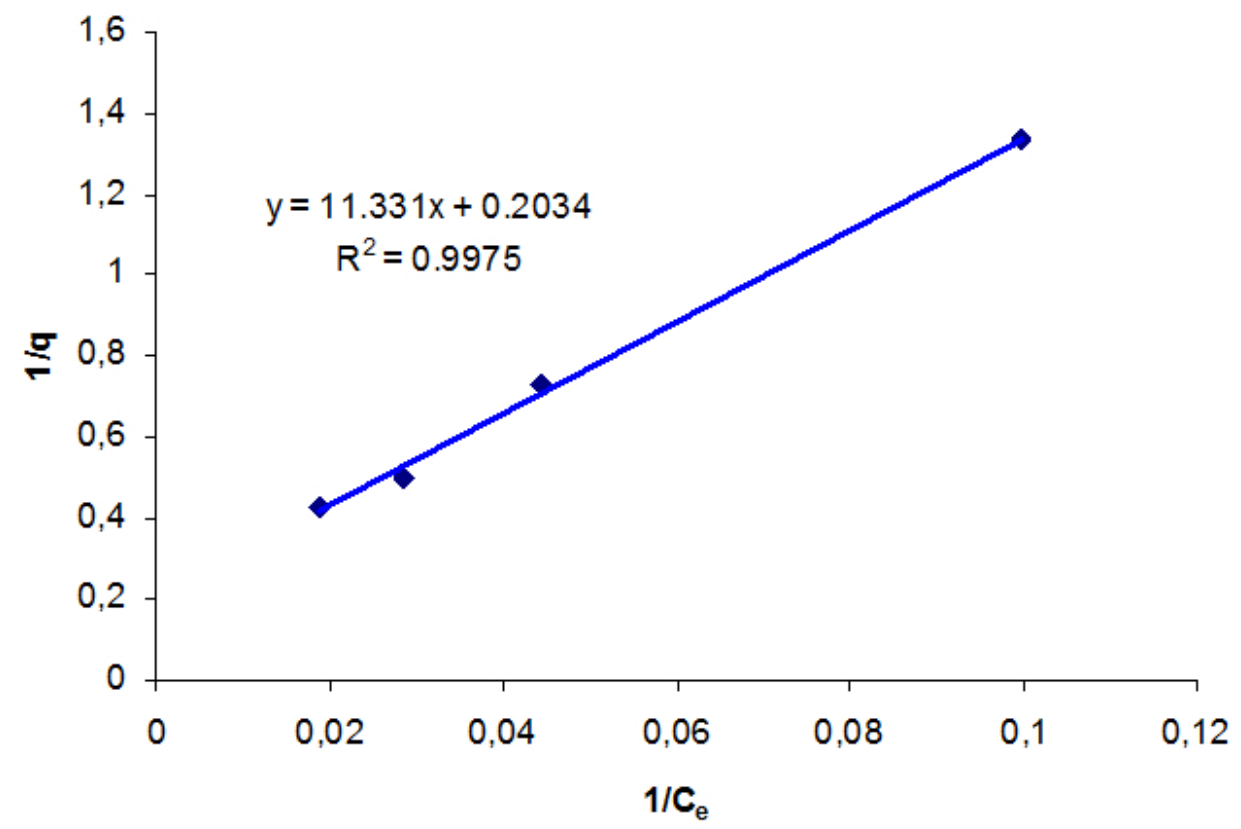

Figure 9. Langmuir isotherm for lead biosorption by Saccharomyces cerevisiae from battery manufacturing industrial effluent. 


\section{Tables}

Table 1. Characteristics of battery manufacturing industrial effluent.

\begin{tabular}{|c|c|c|}
\hline SI. No. & Parameter & Concentration* $^{*}$ \\
\hline 1 & $\mathrm{pH}$ & 5.2 \\
\hline 2 & TSS & $45 \pm 2.3$ \\
\hline 3 & Sulphate & $380 \pm 20$ \\
\hline 4 & $\mathrm{COD}$ & $65 \pm 3.1$ \\
\hline 5 & $\mathrm{Mn}$ & $0.32 \pm 0.02$ \\
\hline 6 & $\mathrm{Ni}$ & $0.28 \pm 0.01$ \\
\hline 7 & $\mathrm{Fe}$ & $0.28 \pm 0.01$ \\
\hline 8 & $\mathrm{Zn}$ & $0.89 \pm 0.05$ \\
\hline 9 & $\mathrm{~Pb}$ & $102 \pm 3.6$ \\
\hline 10 & $\mathrm{Cr}$ & $0.07 \pm 0.01$ \\
\hline
\end{tabular}

*All values are in $\mathrm{mg} / \mathrm{L}$ except $\mathrm{pH}$. Values are mean of 5 replicates.

Table 2. Functional groups of Saccharomyces cerevisiae.

\begin{tabular}{|c|c|c|}
\hline SI. No. & $\mathrm{pK}_{\mathrm{H}}$ value $\left({ }^{*}\right)$ & Functional Group \\
\hline 1 & $5.6( \pm 0.04)$ & Carboxyl \\
\hline 2 & $6.63( \pm 0.02)$ & Phosphate \\
\hline 3 & $9.51( \pm 0.03)$ & Amine \\
\hline \multicolumn{2}{|c|}{ *Standard deviations are given in parentheses. }
\end{tabular}

Table 3. Effect of chemical treatment of Saccharomyces cerevisiae on lead biosorption from battery manufacturing industrial effluent.

\begin{tabular}{|c|c|c|}
\hline SI. No. & Chemical treatment & $(*)$ Effect (\%) \\
\hline 1 & Methylation of amines & $(-) 53.38$ \\
\hline 2 & Esterification of carboxylic acids & $(-) 96.34$ \\
\hline 3 & Esterification of phosphates & $(-) 17.61$ \\
\hline 4 & Modification of sulfhydryl group & $(-) 2.35$ \\
\hline 5 & Extraction of lipids & $(-) 35.68$ \\
\hline
\end{tabular}

$\left({ }^{*}\right)(-)$ signifies negative effect.

Table 4. Isotherm constants for lead biosorption by Saccharomyces cerevisiae from battery manufacturing industrial effluent.

\begin{tabular}{|c|c|c|c|}
\hline SI. No. & & therm consta & \\
\hline \multirow{3}{*}{1} & \multirow{3}{*}{ Freundlich } & $\mathrm{R} 2$ & 0.998 \\
\hline & & Kf & 0.5149 \\
\hline & & $1 / n$ & 1.1871 \\
\hline \multirow{3}{*}{2} & \multirow{3}{*}{ Langmuir } & $\mathrm{R} 2$ & 0.9975 \\
\hline & & Qmax (mg/g) & 55.71 \\
\hline & & b (L/mg) & 0.0883 \\
\hline
\end{tabular}


Parvathi, K. et al.

Table 5. Comparison of isotherm constants for lead biosorption available in literature.

\begin{tabular}{|c|c|c|c|c|c|}
\hline SI. No. & Type of biomass & $\begin{array}{c}\text { Freundlich } \\
\text { constant Kf }\end{array}$ & $\begin{array}{c}\text { Langmuir constant } \\
\text { Qmax (mg/g) }\end{array}$ & $\begin{array}{c}\text { Maximum } \\
\text { concentration } \\
\text { used (mg/L) }\end{array}$ & Reference \\
\hline 1 & Saccharomyces cerevisiae & 0.5149 & 55.71 & 100 & Present study \\
\hline 2 & Rhizopus nigricans & 72.43 & 403.2 & 1000 & Kogej and Pavko, 2001 \\
\hline 3 & Strepytomyces rimosus & 30.1 & 137 & 750 & Selatnia et al. 2004 \\
\hline 4 & Phanerochaete chrysosporium & 5.406 & 61.35 & 30 & Yetis et al. 2000 \\
\hline 5 & Sago waste & 16.84 & 46.64 & 200 & Quek et al. 1998 \\
\hline 6 & Neurospora crassa & 1.4 & 43.29 & 100 & Kiran et al. 2005 \\
\hline 7 & Enterobacter sp. & 15.5 & 50.9 & 500 & Lu et al. 2006 \\
\hline
\end{tabular}

